\title{
Impact of Interest Rate Shocks on the Asset Structure of Private Households in Germany with Particular Reference to Insurance
}

\author{
Tim Linderkamp \\ Center for Risk and Insurance, Hannover, Germany
}

Email address:

tl@kvw-hannover.de

To cite this article:

Tim Linderkamp. Impact of Interest Rate Shocks on the Asset Structure of Private Households in Germany with Particular Reference to Insurance. Applied and Computational Mathematics. Special Issue: Computational Methods in Monetary and Financial Economics. Vol. 5, No. 1-1, 2015, pp. 14-20. doi: 10.11648/j.acm.s.2016050101.12

\begin{abstract}
This paper investigates the portfolio structure of private households in Germany from 1994 to 2014. We focus on the question of how sensitively private households react to a shock in the interest rate level. We use a vector autoregressive model and analyze the corresponding impulse-response functions. The data set is provided by Deutsche Bundesbank. Our hypothesis that the asset class Insurance reacts less sensitively to changes in the interest rate level than other asset classes cannot be confirmed. In general, the results show almost no reactions in the portfolio proportions after an interest rate shock. From our results, it appears that private households in Germany clearly do not integrate interest rate information into their portfolio allocation decisions.
\end{abstract}

Keywords: Insurance, Demand Motives, Asset Structure, Private Households, Interest Rate

\section{Introduction}

Private households in Germany had amassed a wealth stock of 5.206 billion euros by the beginning of 2014 . Insurance contracts are one of the classic assets of private households, with the investment strategy of private households depending on various determinants and motives.

The declining performance of the statutory pension system in Germany has forced the younger generation in particular to increase private provision for old age. For this type of capital accumulation, life insurance policies and private pension schemes are appropriate products, because they focus on the hedging motive and there is almost no risk of loss for this type of investment. Also, considering the returns of life insurance products, private households can receive competitive risk-return profiles [1].

Data from the Deutsche Bundesbank show that demand for insurance products is increasing, despite their already high proportion of the portfolio of private households. We try to show the reasons for this development through a comparison with other asset classes. The main focus of this article is the investigation of the demand motives of private households. The demand for insurance products should be driven primarily by the need for security of investments in retirement and only secondarily by the motive to receive high returns. We suppose therefore that the demand for the asset class Insurance reacts less sensitively to changes in interest rates when compared with the demand for other asset classes.

This hypothesis will be investigated using time series analysis. We use quarterly data on the wealth accumulation of private households provided by the Deutsche Bundesbank [2] from Q3 1994 until Q1 2014.

The paper is structured as follows: Section 2 provides a literature overview with regard to the investment behavior of private households on the one hand, and with regard to demand motives for life insurance and private pension schemes on the other. Section 3 includes an initial descriptive analysis of the Deutsche Bundesbank data. In addition, the methodology of vector autoregressive (VAR) models and impulse-response functions is briefly outlined. Section 4 presents the results, while Section 5 discusses and Section 6 summarizes the main findings.

\section{Literature Overview}

Ruprecht and Wolgast [2] examine the impact of demographic changes on the demand for insurance and pension products, in particular for life insurance cover. The 
decline in population will have no significant impact until the year 2020; however, 2020 is the date until any investment in retirement products should be done to compensate the impact of the reduced benefits of the statutory pension scheme. Moreover, the age structure in Germany is changing, which directly influences the savings rate1, with this rate known to be correlated with age.

In addition, a change in the motives for saving is predicted. Due to the current sufficiency of payments by the statutory pension insurance, at present, the main savings motives are saving for major investments or precautionary saving. Saving to provide for old age will become more important in the future. 2

The need for private provision is recognized by private households, but there is an insufficient effort to close potential gaps in retirement benefits. The reasons for this include a lack of information about the retirement gap, illusions about inheritance bequests, and a deep confidence that the state will not let whole cohorts of the population slip into old-age poverty ("lender of last resort").

Life insurance policies and private pension schemes, which are characterized by high reliability and a low risk of return, are predesigned to engage the precautionary motive for saving. They offer an attractive return, are flexible (allowing for a lump-sum option), are long-term oriented and suitable for covering biometric risks such as death, disability, or longevity.

Müller [5] arranged the demand motives for insurance products into two groups: security and asset accumulation.

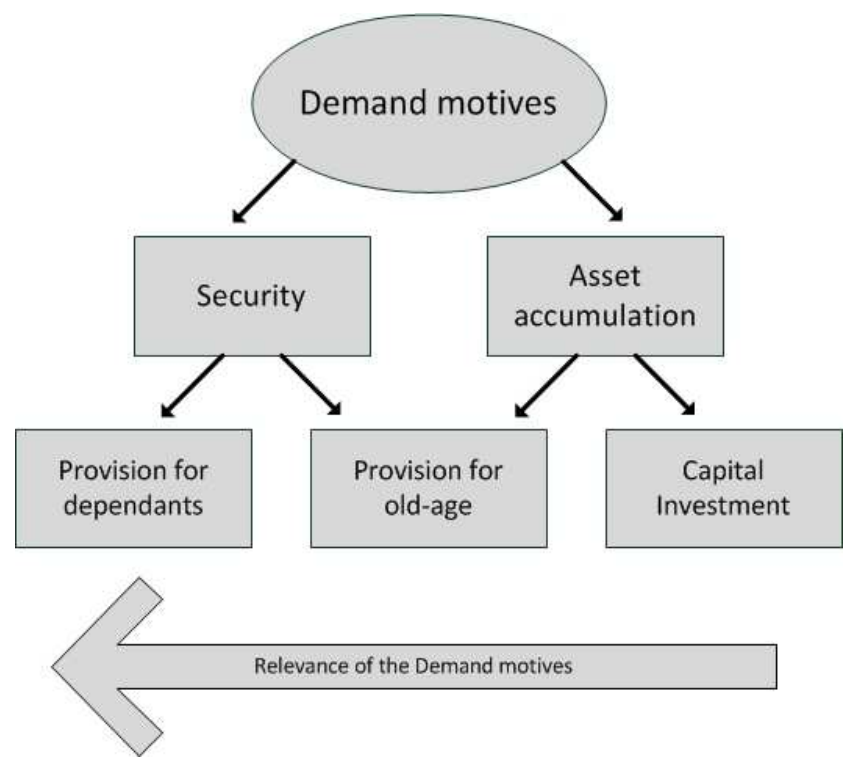

Figure 1. Demand motives for life insurances3.

From the motive of security, Müller derives provision for dependants and provision for old age as demand motives for insurance. The motive of asset accumulation is also split into provision for old age and capital investment. Müller attaches the highest importance as demand motives for insurance to provision for dependants, followed by provision for old age and capital investment.
Wähling, Trumpfheller, and Graf von der Schulenburg [6] empirically confirm the motive structure outlined by Müller. Their survey findings show that the motives of provision for dependants and provision for old age are the main reasons for buying a life insurance policy.

On the question of the sensitivity of life insurance demand to interest rates, Müller refers to the weighting of the various demand motives. If "provision for dependants" is the dominant motive, he assumes that there is "no or only very limited" [5] (p. 209) correlation between the life insurance demand and the interest rate.

According to Müller, the specific nature of life insurance products leads to unique selling points that explain the consistently high demand for insurance products. In this regard, he mentioned the long-term orientation longevity and relatively high premiums of these products. The "association of insurance contracts with negative events" [7] (p. 20), e.g., own death or illness, is also characteristic of insurance products and underlines once again the importance of the security motive.

Knospe [8] cites the "flight out of shares [of private households]" (p. 1083) as an essential motive for the increased demand for insurance products. After the bursting of the dotcom bubble, households rearranged their portfolios and purchased insurance products, real estate, and money market funds. The Riester pension scheme, introduced in 2002 , did not lead to a reduction in private old-age provision efforts due to substitution effects. Moreover, the increasing volatility of the financial markets led private households to invest more in safe assets and to diversify their portfolios.

Sauter [9] sees risk in that heightened security needs lead to an increasing demand for low-return assets. With such assets, it is quite uncertain as to whether private households are able to build sufficient capital stock to live from in old age. The financial crisis increased this problem. Moreover, Sauter notes the correlations between risk aversion and age. Younger households are especially risk averse and purchase low-return assets due to an increased need for security.

\section{Data and Methods}

\subsection{Data}

The analysis of the asset structure of private households in Germany is based on detailed data from the Deutsche Bundesbank [2]. The period under review covers Q3 1994 to Q1 2014. All data are consistent with the methodology of the European System of Accounts (ESA 95). The German Bundesbank collects quarterly data of the assets of private households both as a whole and broken down by various asset classes. 4

The insurance time series of concern consists of the aggregate claims of private households from insurance contracts as well as unearned premiums; it is therefore an indicator of the extent to which households accumulate their wealth from life insurance products. From 1994 to 2014, German households tripled their accumulated capital in life 
insurance contracts from 487 billion euros to 1,578 billion euros in 2014. Aside from cash and deposits, 5 insurance claims are in relative terms the dominant asset class with a current share of $30 \%$ of the private household portfolio. Figure 3 shows the relative share of total household wealth of the various asset classes over time.

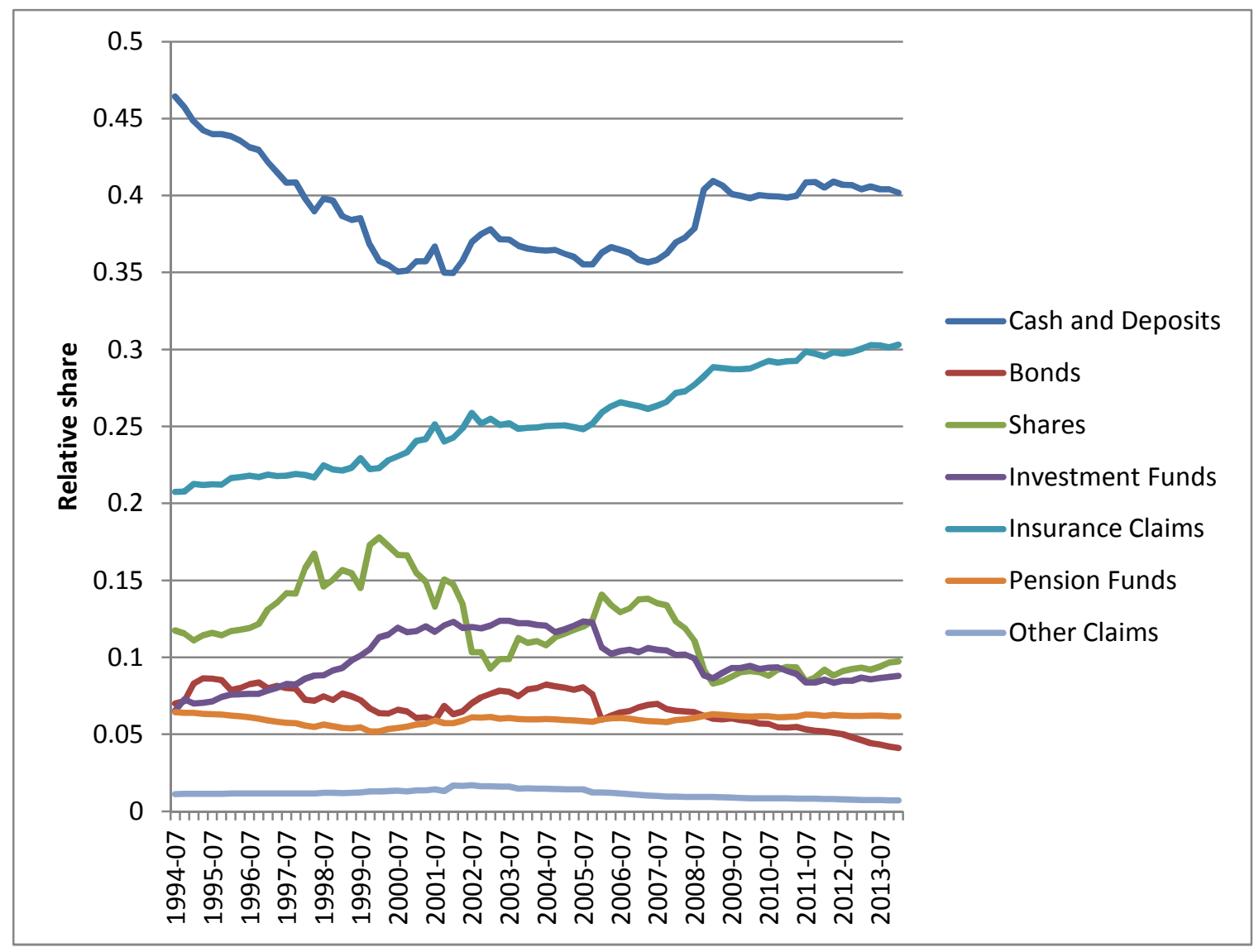

Figure 2. Relative share of asset classes over time6.

Over time, the share of Cash and Deposits decreased from over $45 \%$ in 1994 to $35 \%$ in 2007 ; it has been at around $40 \%$ since April 2010.

The asset class Bonds consists of (short-term) money market instruments and (longer-term) term securities. The importance of money market securities within this asset class is minor with an average share of about $2 \%$.

The equity share of the financial assets of private households varies in the period of observation. Starting with a share of $12 \%$ in 1994 , the proportion of Shares increases to over $17 \%$ in the first quarter of 2000 . After the bursting of the new economy bubble, the equity share drops to less than $10 \%$, recovers in the following years and returns to $10 \%$ at the beginning of the financial crisis in Q3 2008.

Investment certificates as shares in investment funds maintain an average proportion of about $10 \%$ of private household portfolios. Finally, the proportions of claims against Pension Funds and Other Claims 7 are relatively constant over time at $6 \%$ and $1 \%$ respectively.

\subsection{The VAR Model}

To investigate the initial hypothesis that the proportion of insurance claims in the portfolio of private households is less sensitive to interest rates than the proportion of other assets, a vector autoregressive model is used. The VAR model does not require an underlying theoretical model. In VAR models, variables are explained through their past forms and by other endogenous and exogenous variables as well as their past forms [12].Thus, the mutual interactions between the variables are taken into account. These interdependencies have central importance in the analysis of the present data. So it can be assumed, for example, that the proportion of cash and deposits of the total portfolio also depends on the proportion of less liquid assets, such as longer-term bonds. Households are exposed to a tradeoff between the desire for liquidity and the desire for attractive returns.

The variables used in the VAR model have to be stationary. We can distinguish between strict and weak stationarity.

A process is strictly stationary if for all integers $h$ and $\mathrm{n} \geq 1,\left(\mathrm{X}_{1}, \ldots, \mathrm{X}_{\mathrm{n}}\right)$ and $\left(\mathrm{X}_{1+\mathrm{h}}, \ldots, \mathrm{X}_{\mathrm{n}+\mathrm{h}}\right)$ have the same distribution [13].

Weak stationarity, which is adequate for our model, has to fulfill the following conditions:

$$
\begin{gathered}
\mathrm{E}\left[\mathrm{X}_{\mathrm{t}}\right]=\mu_{\mathrm{t}}=\mu \\
\mathrm{V}\left[\mathrm{X}_{\mathrm{t}}\right]=\sigma^{2} \text { and } \mathrm{V}\left[\mathrm{X}_{\mathrm{t}}\right]<\infty \\
\gamma_{\mathrm{X}}(\mathrm{t}, \mathrm{s})=\gamma_{\mathrm{X}}(\mathrm{t}+\mathrm{r}, \mathrm{s}+\mathrm{r})
\end{gathered}
$$


We thus require a constant $\mu$ for all $t$, a constant and finite variance $\sigma^{2}$ for all $t$, and a covariance function that depends only on the time interval $r$ of the random variables $s$ and $t$. The property of stationarity is a necessary requirement to exclude spurious regression.

The proportions of the selected asset classes of the portfolio of private households and the yield of 10-year Bunds are construed as a time series and are tested with the
Augmented Dickey Fuller (ADF) test for stationarity. The null hypothesis that the unit root is zero and thus that there is no stationary time series is rejected if the value of the test statistic is less than the critical value at the relevant significance level.8

Table 1 shows the results of the ADF tests for the individual assets.

Table 1. Results of ADF test.

\begin{tabular}{llll}
\hline Time Series & ADF test statistic of the original time series & ADF test statistic of first differences & Critical value for $\boldsymbol{\alpha}=\mathbf{0 . 0 5}$ \\
\hline Cash and Deposits & 2.1111 & -4.5323 & -2.86 \\
Bonds & -0.1307 & -5.3576 & -2.86 \\
Shares & 0.1975 & -4.9061 & -2.86 \\
Investment Funds & 1.09 & -4.8685 & -2.86 \\
Insurance Claims & 4.4388 & -4.4199 & -2.86 \\
Pension Funds & 2.4904 & -2.6730 & -2.86 \\
Other Claims & 0.0909 & -4.1652 & -2.86 \\
Yield of 10-year Bund & -1.5446 & -5.116 & -2.86 \\
\hline
\end{tabular}

The first column of results shows that none of the time series is stationary. We calculate the first differences of the time series and now find stationarity in all time series except Pension Funds (see the second results column). The asset class Pension Funds is therefore excluded from our model. As the first descriptive impression in Figure 1 also indicated, this asset class is not central for our analysis.

As mentioned above, in a VAR model the variables are explained by their past forms as well as other variables and their past forms.

A SVAR model9 with time series $Y_{t}$ and $Z_{t}$ is given by 10

$$
\begin{aligned}
& \mathrm{Y}_{\mathrm{t}}=\beta_{10}-\beta_{12} \mathrm{Z}_{\mathrm{t}}+\sum_{\mathrm{i}=1}^{\mathrm{p}} \delta_{11 \mathrm{i}} \mathrm{Y}_{\mathrm{t}-\mathrm{i}}+\sum_{\mathrm{i}=1}^{\mathrm{p}} \delta_{12 \mathrm{i}} \mathrm{Z}_{\mathrm{t}-\mathrm{i}}+\varepsilon_{\mathrm{yt}} \\
& \mathrm{Z}_{\mathrm{t}}=\beta_{20}-\beta_{21} \mathrm{Y}_{\mathrm{t}}+\sum_{\mathrm{i}=1}^{\mathrm{p}} \delta_{21 \mathrm{i}} \mathrm{Y}_{\mathrm{t}-\mathrm{i}}+\sum_{\mathrm{i}=1}^{\mathrm{p}} \delta_{22 \mathrm{i}} \mathrm{Z}_{\mathrm{t}-\mathrm{i}}+\varepsilon_{\mathrm{zt}} .
\end{aligned}
$$

Here $\varepsilon_{\mathrm{yt}}$ and $\varepsilon_{\mathrm{zt}}$ are shocks in the respective time series. 11

With a lag length of 1 and in matrix notation, we can write the SVAR model as

$$
\left(\begin{array}{cc}
1 & \beta_{12} \\
\beta_{21} & 1
\end{array}\right)\left(\begin{array}{l}
Y_{\mathrm{t}} \\
\mathrm{Z}_{\mathrm{t}}
\end{array}\right)=\left(\begin{array}{l}
\beta_{10} \\
\beta_{20}
\end{array}\right)+\left(\begin{array}{ll}
\delta_{11} & \delta_{12} \\
\delta_{21} & \delta_{22}
\end{array}\right)\left(\begin{array}{l}
\mathrm{Y}_{\mathrm{t}-1} \\
\mathrm{Z}_{\mathrm{t}-1}
\end{array}\right)+\left(\begin{array}{l}
\varepsilon_{\mathrm{yt}} \\
\varepsilon_{\mathrm{zt}}
\end{array}\right)
$$

with $\quad \mathrm{B}=\left(\begin{array}{cc}1 & \beta_{12} \\ \beta_{21} & 1\end{array}\right), \quad \mathrm{x}_{\mathrm{t}}=\left(\begin{array}{l}\mathrm{Y}_{\mathrm{t}} \\ \mathrm{Z}_{\mathrm{t}}\end{array}\right), \quad \Gamma_{0}=\left(\begin{array}{l}\beta_{10} \\ \beta_{20}\end{array}\right), \quad \Gamma_{1}=$ $\left(\begin{array}{ll}\delta_{11} & \delta_{12} \\ \delta_{21} & \delta_{22}\end{array}\right), \varepsilon_{\mathrm{t}}=\left(\begin{array}{c}\varepsilon_{\mathrm{yt}} \\ \varepsilon_{\mathrm{zt}}\end{array}\right)$

or as $\mathrm{Bx}_{\mathrm{t}}=\Gamma_{0}+\Gamma_{1} \mathrm{x}_{\mathrm{t}-1}+\varepsilon_{\mathrm{t}}$.

Multiplying by $\mathrm{B}^{-1}$ from the left, we get the VAR model in standard form:

$$
x_{t}=A_{0}+A_{1} x_{t-1}+\omega_{t}
$$

with $\mathrm{A}_{0}=\mathrm{B}^{-1} \Gamma_{0}, \mathrm{~A}_{1}=\mathrm{B}^{-1} \Gamma_{1}$ and $\omega_{\mathrm{t}}=\mathrm{B}^{-1} \varepsilon_{\mathrm{t}}$

In addition, $\alpha_{i 0}$ is the ith element of the vector $A_{0}, \alpha_{i j}$ is the entry in the ith row and jth column of the matrix $A_{1}$, and $\omega_{\text {it }}$ is the ith entry of the vector $\omega_{t}$.

Thus, we can write:

$$
Y_{t}=\alpha_{10}+\alpha_{11} Y_{t-1}+\alpha_{12} Z_{t-1}+\omega_{1 t}
$$

and

$$
\mathrm{Z}_{\mathrm{t}}=\alpha_{20}+\alpha_{21} \mathrm{Y}_{\mathrm{t}-1}+\alpha_{22} \mathrm{Z}_{\mathrm{t}-1}+\omega_{2 \mathrm{t}}
$$

In the following argument, the concept of impulseresponse functions is introduced briefly, with reference to (3.1) and (3.2).

Impulse-response functions provide a way to study the effects of a simulated interest rate shock on the proportions of the various asset classes in the investment portfolio of private households. They show the impact of the shocked variable on other variables (here the relative proportions of the asset classes) over time.

As mentioned in the example above, the shocks (at the level of $\sigma$ ) are reflected in $\varepsilon_{\mathrm{yt}}$ and $\varepsilon_{\mathrm{zt}}$ in the model. They affect $\omega_{1 \mathrm{t}}$ and $\omega_{2 \mathrm{t}}$ as follows:

$$
\omega_{1 \mathrm{t}}=\frac{\left(\varepsilon_{\mathrm{yt}}-\beta_{12} \varepsilon_{\mathrm{zt}}\right)}{\left(1-\beta_{12} \beta_{21}\right)} \text { and } \omega_{2 \mathrm{t}}=\frac{\left(\varepsilon_{\mathrm{zt}}-\beta_{21} \varepsilon_{\mathrm{yt}}\right)}{\left(1-\beta_{12} \beta_{21}\right)} .
$$

$\omega_{1 \mathrm{t}}$ and $\omega_{2 \mathrm{t}}$ are correlated as follows: $\gamma\left(\omega_{1 \mathrm{t}}, \omega_{2 \mathrm{t}}\right)=$ $\frac{-\left(\beta_{21} \sigma_{\mathrm{y}}^{2}+\beta_{12} \sigma_{\mathrm{z}}^{2}\right)}{\left(1-\beta_{12} \beta_{21}\right)^{2}}$.

Due to this correlation, the effects of the shocks are no longer isolated. To ensure that we can measure isolated shocks, the VAR model has to be transformed: multiplication of (3.1) by $\lambda=\frac{\sigma_{12}}{\sigma_{1}^{2}}$ and subtraction of (3.2) leads to

$$
\left(\begin{array}{c}
\mathrm{Y}_{\mathrm{t}} \\
\mathrm{Z}_{\mathrm{t}}-\lambda \mathrm{Y}_{\mathrm{t}}
\end{array}\right)=\left(\begin{array}{c}
\alpha_{10} \\
\alpha_{20}^{*}
\end{array}\right)+\left(\begin{array}{cc}
\alpha_{11} & \alpha_{12} \\
\alpha_{21}^{*} & \alpha_{22}^{*}
\end{array}\right)\left(\begin{array}{c}
\mathrm{Y}_{\mathrm{t}-1} \\
\mathrm{Z}_{\mathrm{t}-1}
\end{array}\right)+\left(\begin{array}{c}
\omega_{1 \mathrm{t}} \\
\omega_{2 \mathrm{t}}^{*}
\end{array}\right)
$$

with $\alpha_{2 \mathrm{i}}^{*}=\left(\alpha_{2 \mathrm{i}}-\lambda \alpha_{1 \mathrm{i}}\right)$, for $\mathrm{i}=0,1,2$ and $\omega_{2 \mathrm{t}}^{*}=\left(\omega_{2 \mathrm{t}}-\right.$ $\left.\lambda \omega_{1 \mathrm{t}}\right)$.

After this transformation, $\omega_{1 \mathrm{t}}$ and $\omega_{2 \mathrm{t}}^{*}$ are no longer correlated [17]. Now we can investigate the effect of isolated, so-called orthogonal shocks.

Moreover, we generated empirical distribution functions for random variables whose theoretical distribution is not known, as with the case of the impulse-response functions, 
using bootstrapping. Based on the empirical distribution functions generated and their confidence intervals, we examine whether any shock effects that can be expressed by the impulse-response function are significant at the chosen $5 \%$ level.

\section{Results}

We estimate a VAR model with the time series of the 10year Bund, the relative proportions of Cash and Deposits, Bonds, Shares, Investment Funds, Insurance Claims, and Other Claims as endogenous variables. The composite DAX (CDAX) is integrated as an exogenous variable in the model to explain the qualitative changes in shares through rate changes and to separate them from quantitative changes, e.g., by a lower participation rate of households in the equity market.12 This ensures that any reaction of the equity share of the household portfolio to a shock of the interest rate is only quantitatively based and not value based.

With the model specification able to consider at least four time lags, the Akaike Information Criterion recommends the inclusion of four lags for endogenous as well as for exogenous variables. Figures 3 and 4 below present the results as impulse-response functions. The proxy for private households' relevant interest rate, the 10-year Bund yield, represents a shock in the level of interest rates.

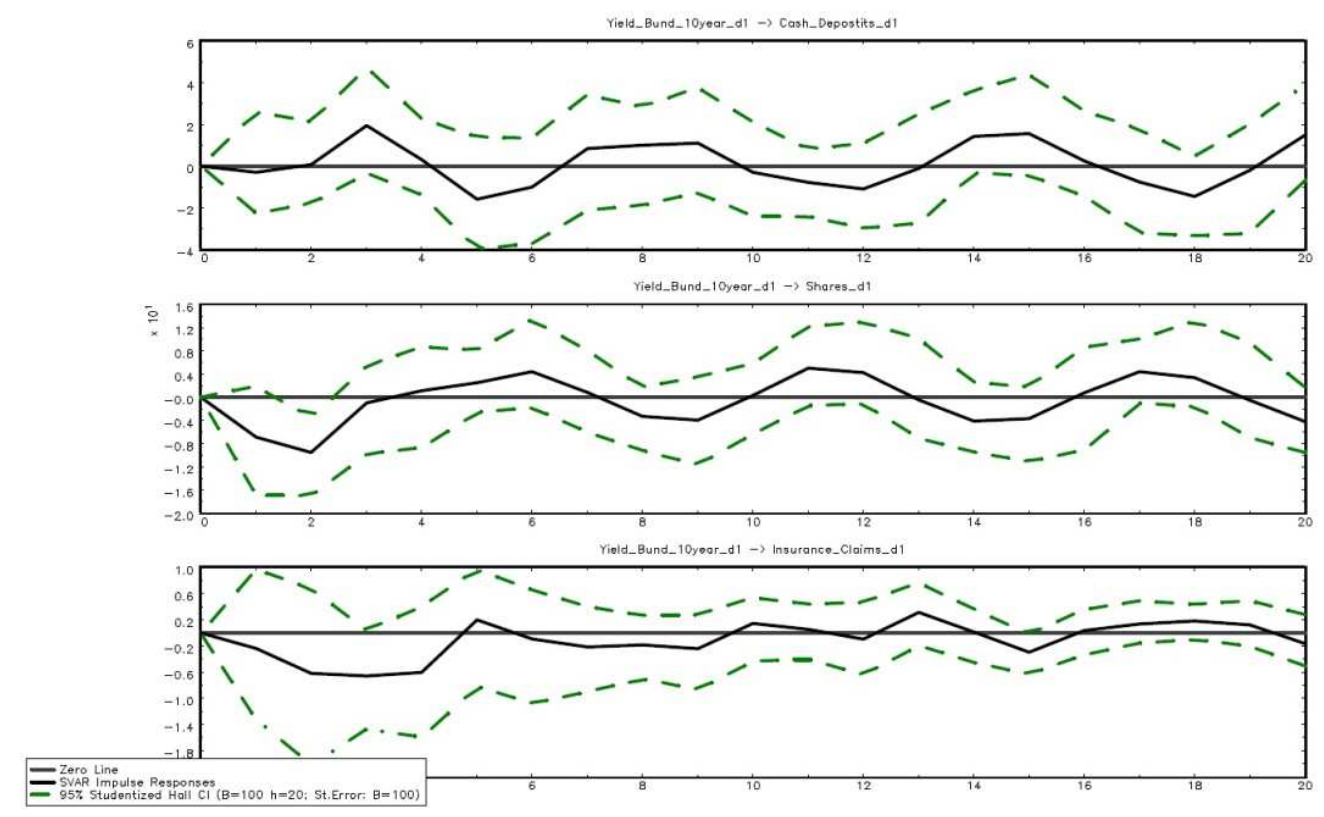

Figure 3. Impulse-Response Function of Cash and Deposits, Shares, and Insurance Claims.

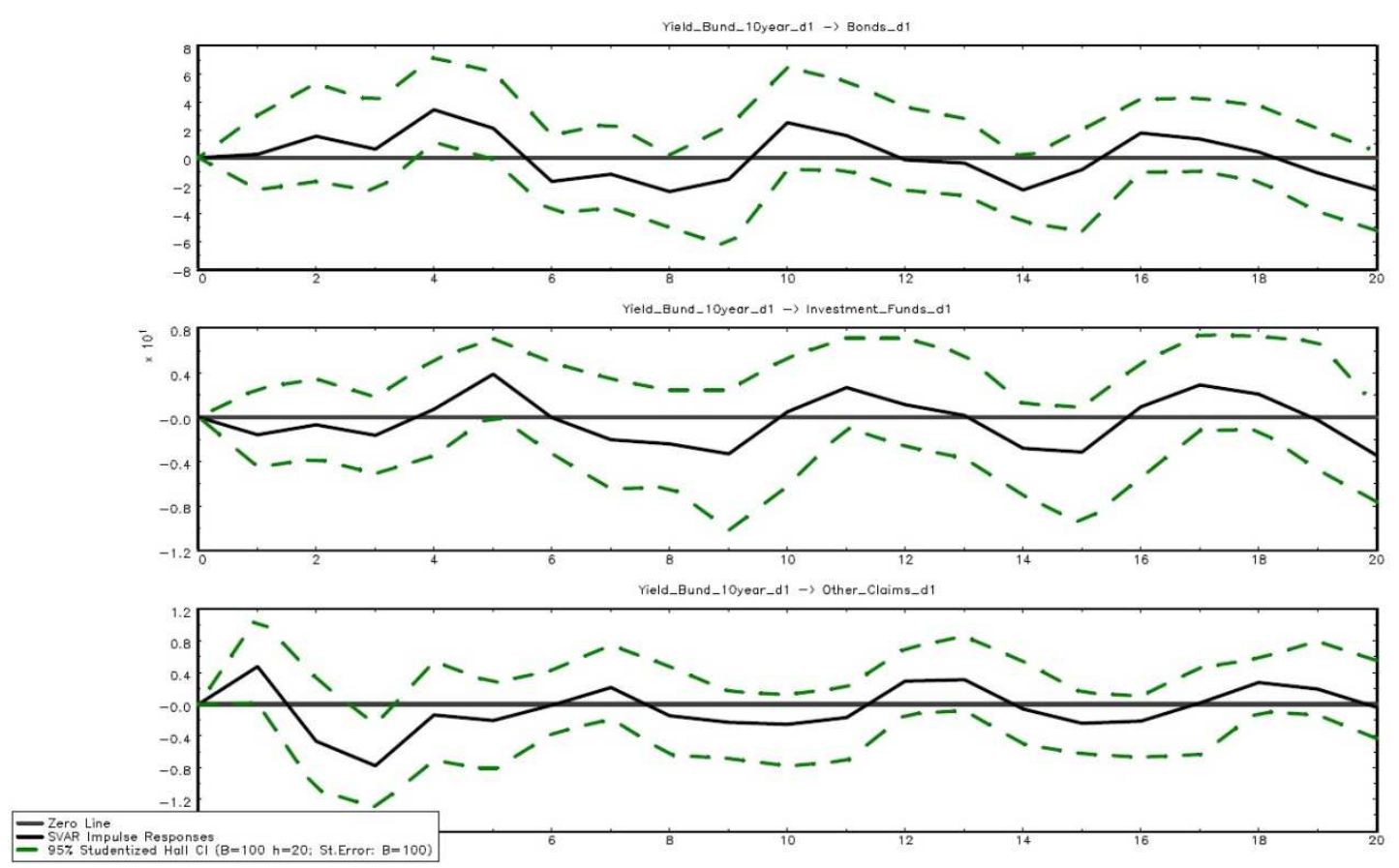

Figure 4. Impulse-Response Function of Bonds, Investments Funds, and Other Claims. 
First, it is noticeable that we cannot confirm our hypothesis that Insurance Claims react less sensitively than other asset classes to an interest rate shock, because other asset classes also generally show insensitive reactions. The results show only three significant reactions to the interest rate shock: for Shares after two quarters, for Bonds after four quarters, and for Other Claims after three quarters. Significance is indicated if the impulse-response function and the corresponding 0.95 interval break through the zero line. Second, although the results are not significant, we find that the shock effects differ in their strength. We should note the different units on the ordinate scales. The reaction of the asset class Investment Funds is the poorest, followed by Shares, Insurance Claims, Other Claims, Cash and Deposits, and Bonds.

\section{Discussion}

The results indicate that private households in Germany do not optimize their portfolios in reaction to interest rate changes. It appears that they cannot handle such information from the capital markets. At the least, we expected a recalibration of the Cash and Deposits proportion in the sense of a positive correlation between the interest rate level and the amount of deposits.

The poor positive significant reactions of the Bond share might be explained by the inverse relationship between market value and yield. In the Bundesbank statistics, bonds are valued at market prices. If the interest rate level rises, the market value of bonds declines and so it is cheaper for private households to purchase them. But it is questionable whether these reactions take place four quarters later, as our results indicate.

For the asset class Shares, the results show a significant negative reaction to an interest rate shock. A possible explanation is the increasing cost of funds for companies and possibly lower returns from stocks. Moreover, the substitution of shares by other, more interest rate-sensitive assets could be assumed in the case of rising interest rates.

Our findings are in line with Dar and Dodds [18] for example. For Great Britain they also show that the demand for life insurances is not correlated with the internal interest rate or the yield of alternative asset classes. Cottin et al. [19] came to the same results for Germany. They show that the amount of participation features as one important part of the return is not correlated with the lapse rate and therefore with the demand for life insurances. But there are other findings like Kiesenbauer [20]. He finds that in Germany the participation feature is correlated positively with the lapse rate.

In general, our model provides only a few robust conclusions. There are of course many limitations concerning our parametric approach, but it is a practical approach to use impulse-response functions to analyze this empirical issue. Moreover, it is quite difficult to identify the relevant interest rate proxy for private households. For each of the asset classes considered, an appropriate interest rate proxy is available, but the model required one proxy that represents the decision- making factor. Third, the asset classes in the model might be relatively heterogeneous in themselves. For example, as mentioned above, the asset class Bonds consists of short-term money market instruments and longer-term securities. Due to the different economic characteristics of such subsets, the interest rate effect on the asset class as a whole could be blurred. A more differentiated consideration could be necessary, wherefore we need longer time series to provide the needed degrees of freedom for our model.

\section{Conclusions}

In this paper, we investigated the role of insurance products in the asset accumulation of private households in Germany. Our hypothesis is that the demand for insurance is not primarily determined by yield motives, but by other motives, especially safety. To test this hypothesis, we use a vector autoregressive model to estimate the interest rate sensitivity of insurance claims and other asset classes.

We find that insurance claims generally do not react significantly to a change in the interest rate. However, we do find significant interest rate reactions for the asset classes Bonds, Shares, and Other Claims. Overall, it appears that private households do not integrate interest rate information into their portfolio allocation decisions.

The insurance industry should be aware of those motives of households that are relevant for the demand for insurance products. We would argue that the high need for security is dominant here. Households will have to expand their private pension activities and therefore need adequate insurance products. It is also necessary to highlight even more clearly the strengths of life and pension insurance products, such as their long-term orientation and high investment security.

\section{References}

[1] W. Ruprecht and M. Wolgast, "Die Märkte für Altersvorsorge in Deutschland, Eine Analyse bis 2020" in Gesamtverband der Deutschen Versicherungswirtschaft e.V., Eds., Schriftenreihe des Ausschusses Volkswirtschaft, No. 23, 2004.

[2] [2] Deutsche Bundesbank, Makroökonomische Zeitreihen: Finanzierungsrechnung der privaten Haushalte nach ESVG 1995, $2014 . \quad$ URL: http://www.bundesbank.de/Navigation/DE/Statistiken/Zeitreih en_Datenbanken/Makrooekonomische_Zeitreihen/its_list_nod e.html?listId=www_v39_phgvx.

[3] H. Bardt and M. Grömling, "Sparen in Deutschland und den USA,“iw-trends, No. 3, 2003.

[4] Verband der Privaten Bausparkassen e.V., „Sparklima-Das Verhalten der Bundesbürger", 2010. URL: http://www.bausparkassen.de/index.php?id=54.

[5] A. Müller, "Erklärung der Lebensversicherungsnachfrage anhand ökonomischer und psychologischer Einflussfaktoren," in Müller-Lutz and Helten, Eds., Beiträge zu wirtschaftswissenschaftlichen Problemen der Versicherung, Band 40, Karlsruhe: VVW Verlag, 1998. 
[6] S. Wähling, J. Trumpfheller, and J.M. Graf von der Schulenburg, "Die Nachfragemotive nach Kapitallebensversicherungen und ihre Struktur," Versicherungswirtschaft, Vol. 48, No. 3, 1993, pp. 173-180.

[7] W.W. Kurtenbach, K. Kühlmann, and G. Kässer-Pawelka, „Versicherungsmarketing - Eine praxisorientierte Einführung in das Marketing für Versicherungen und ergänzende Finanzdienstleistungen“, 3. Frankfurt am Main: Auflage, Fritz Knapp Verlag, 1992.

[8] J. Knospe, "Bundesbürger favorisieren Versicherungen," Versicherungswirtschaft, Vol. 58, No. 14, 2003, pp. 1082 1083.

[9] N. Sauter, "Das schwache Pflänzchen Aktienkultur," Working Paper 139, Economic Research \& Corporate Development, Allianz AG, 2010.

[10] Deutsche Bundesbank Ergebnisse der gesamtwirtschaftlichen Finanzierungsrechnung für Deutschland 1991 bis 2009, Statistische Sonderveröffentlichung 4, Frankfurt am Main: Verlag der Deutschen Bundesbank, 2010.

[11] Regulation (EC) No. 2223/96 of 25 June 1996 on the European system of national and regional accounts in the Community.

[12] R. Gerke and T. Werner, "Monetäre Schocks in VAR Modellen," Arbeitspapiere des Instituts für Volkswirtschaftslehre, No. 106, Technische Universität Darmstadt, 2001.

[13] K. Neusser, Zeitreihenanalyse in den Wirtschaftswissenschaften, 2. Aktualisierte Auflage,
Wiesbaden: Vieweg und Teubner Verlag, 2009.

[14] R. Davidson and J. MacKinnon, Estimation and Inference in Econometrics, London: Oxford University Press, 1993.

[15] H. Rinne and K. Specht, Zeitreihen-Statistische Modellierung, Schätzung und Prognose, München: Verlag Vahlen, 2002.

[16] A. Schweinberger, "Ein VAR-Modell für den Zusammenhang zwischen Öffentlichen Ausgaben und Wirtschaftswachstum in Deutschland," Arbeitspapier No. 30, Mainz: Institut für Statistik und Ökonometrie, 2004.

[17] W.W. Charemza and D.F. Deadman, New Directions in Econometric Practice, 2nd Edition, Cheltenham: Edward Elgar Publishing Limited, 1997.

[18] D. Dar and C. Dodds, "Interest Rates, the Emergency Fund Hypothesis and Saving through Endowment Policies: Some Empirical Evidence for the UK," The Journal of Risk and Insurance, Vol. 56, No. 3, 1989, pp. 415-433.

[19] C. Cottin, V. Heinke, W. Homann and C. Sander, "Empirische Analyse des Einflusses der Überschussbeteiligung auf Neugeschäft und Storno," Zeitschrift für die gesamte Versicherungswissenschaft, Vol. 96, No. 3, 2007, pp. 339-373.

[20] D. Kiesenbauer, "Main Determinants of Lapse in the German Life Insurance Industry, 2011. URL: https://www.uniulm.de/fileadmin/website_uni_ulm/mawi2/forschung/preprintserver/2011/1103_lapse.pdf.

1 For an international overview, see Bardt and Grömling [3].

2 In contrast, a survey of "Verbandes der Privaten Bausparkassen e.V." states

"provision for old age" as the most important saving motive with $61.5 \%$, followed by the motive "consumption" with $51.9 \%$ [4].

3 Own representation based on Müller [5].

4 For the definitions of these asset classes and the distinctions among them, see

Deutsche Bundesbank [10] (p. 7) and Regulation (EC) No. 2223/96 [11] (p. 144).

5 Deposits are defined as assets that can be converted in cash at any time.

6 Own representation based on data of Deutsche Bundesbank [2].

7 Other claims arise from the fact that there is a time lag between transactions and their payment. See Regulation (EC) No. 2223/96 [11] (p. 157).

8 For the critical values of the test statistic, see Davidson and MacKinnon [14].

$9 Y_{t}$ and $Z_{t}$ are influenced by each other, so it is a structural VAR model (SVAR)

[15].

10 See Schweinberger [16].

$11 \varepsilon_{y t}$ and $\varepsilon_{z t}$ are white noise.

12 We choose the CDAX performance index because this reflects all shares,

notated in the general and in the prime standard. Moreover, it takes all dividend

payments into account. 